\title{
Effects of angico extract (Anadenanthera colubrina var. cebil) in cutaneous wound healing in rats ${ }^{1}$
}

\author{
Efeitos do extrato de angico (Anadenanthera colubrina var. cebil) \\ em feridas cutâneas de ratos
}

\author{
Wagner Soares Pessoa', Lígia Reis de Moura Estevão", Ricardo Santos Simões ${ }^{\mathrm{III}}$, Maria Edna Gomes de Barros ${ }^{\mathrm{IV}}$, Fábio de \\ Souza Mendonçav ${ }^{\mathrm{v}}$, Liriane Baratella-Evêncio ${ }^{\mathrm{VI}}$, Joaquim Evêncio-NetovII
}

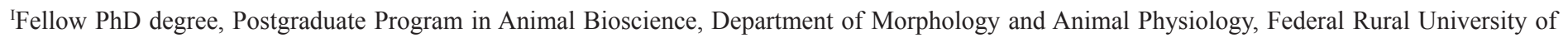
Pernambuco (UFRPE), Pernambuco, Brazil. Acquisition and interpretation of data.

IIFellow PhD degree, Postgraduate Program in Animal Bioscience, Department of Morphology and Animal Physiology, UFRPE, Pernambuco, Brazil. Manuscript writing, critical revision.

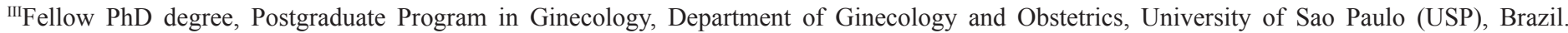
Interpretation of data and manuscript writing.



vAssociate Professor, Histology Division, Department of Morphology, UFRPE, Pernambuco, Brazil. Pathological analysis and manuscript writing.

${ }^{\mathrm{V}}$ Associate Professor, Histology Division, Department of Morphology, UFPE, Pernambuco, Brazil. Conception, design and critical revision.

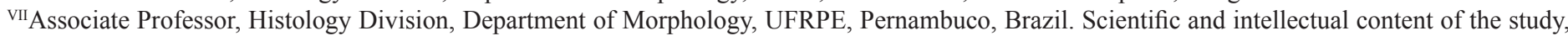
interpretation of data and critical revision.

\begin{abstract}
PURPOSE: To study the effects of the angico extract (Anadenanthera colubrina var. cebil) on the healing of rat skin.

METHODS: Twenty adult rats were divided into four groups of five animals each, the G4, G7, G14 and G21, which corresponds to the respective postoperative days. Each group received two incisions on skin and subcutaneous tissue in the right and left antimere of the thoracic region, separated by a distance of $2 \mathrm{~cm}$. The right lesion was treated daily with saline and the left with the angico alcoholic extract (5\%). At the end of each experimental period, animals were euthanized and fragments of the wound area, together with the edges were removed, fixed in 10\% formaldehyde solution and processed for paraffin embedding. In the histological sections with $5 \mu$ m of thickness, were carried out immunohistochemical methods for detection of blood vessels (VEGF) and stained with hematoxylin and eosin for morphological analysis. Statistical analysis was done by ANOVA and Tukey test $(\mathrm{p}<0.05)$.

RESULTS: Morphological analysis showed larger fibroblasts and a higher concentration of collagen fibers in days 7 and 14 in wounds treated with the angico extract. Morphometric analysis demonstrated a significant increase in the number of blood vessels in both the seventh and 14th days $(\mathrm{p}<0.01)$ in wounds treated with the angico extract.

CONCLUSION: The angico alcoholic extract (Anadenanthera colubrina var. cebil) induces the acceleration of wound healing in skin wounds of rats.

Key words: Wound Healing. Angiogenesis Inducing Agents. Neovascularization, Physiologic. Phytotherapy. Rats.

\section{RESUMO}

OBJETIVO: Avaliar os efeitos do extrato de angico (Anadenanthera colubrina var. cebil) na cicatrização em pele de ratos.

MÉTODOS: Ratos machos adultos $(\mathrm{n}=20)$ foram distribuídos em quatro grupos de cinco animais cada, a saber: G4, G7, G14 e G21, o que corresponde a quatro, sete, 14 e 21 dias de pós-operatório. Cada grupo recebeu duas incisões na pele compreendendo o tecido subcutâneo, nos antímeros direito e esquerdo da região torácica, separadas por uma distância de dois cm. A lesão esquerda com extrato alcoólico de angico (5\%), iniciando-se logo após a cirurgia por 21 dias consecutivos. Ao final de cada período (4, 7, 14 e 21 de pós-operatório) experimental foram coletados fragmentos da área da ferida, fixada em formol a $10 \%$ e processadas para inclusão em parafina. Nos cortes histológicos com $5 \mu \mathrm{m}$ de espessura, foram realizados métodos imunoistoquímicos para detecção dos vasos sanguíneos (VEGF) e coloração pela hematoxilina para análise morfológica. Os dados obtidos foram submetidos à análise estatística ANOVA complementada pelo teste de Tukey-Kramer $(\mathrm{p}<0,05)$.

RESULTADOS: A análise morfológica mostrou fibroblastos mais volumosos e alta concentração de fibras colágenas no $7^{\circ}$ e $14^{\circ}$ dias nas feridas tratadas com extrato de angico. A análise morfométrica demonstrou aumento significativo no número de vasos sanguíneos no sétimo e $14^{\circ}$ dias $(\mathrm{p}<0,01)$ de pós-operatório em feridas tratadas com extrato de angico.
\end{abstract}

CONCLUSÃO: O extrato hidroalcoólico a $5 \%$ da casca e entrecasca do angico (Anadenanthera colubrina var. cebil) acelera a neoangiogênese em feridas cutâneas de ratos.

Descritores: Cicatrização. Indutores da Angiogênese. Neovascularização Fisiológica. Fitoterapia. Ratos. 


\section{Introduction}

Since ancient times, medicinal plants are used for preventive or curative purposes. Primitive human societies already used medicinal plants for diseases treatment. It is believed that ancient populations discovered the healing properties of plants by observing animals that rubbed themselves on the trunks of trees to alleviate or heal their wounds ${ }^{1}$.

Native from the caatinga ecosystem, "Angico" (Anadenanthera colubrina Vell. Brenan) is a plant found in the northeast, southeast and south regions of Brazil. The inner bark contains tannins and has hemostatic, depurative, astringent and healing properties and is commonly used in folk medicine as brew, syrup, tincture or macerated ${ }^{2-4}$. The condensed tannin can also be referred to as proanthocyanidins and are known to improve wound healing ${ }^{5,6}$. The hydroalcoholic extract of angico has in vitro antimicrobial activity against Staphylococcus aureus strains ${ }^{7}$.

The healing process consists of a series of cellular and molecular events that occur, interacting for the rebuilding of the damaged tissue. Under normal conditions, the healing process follows a sequence that can be divided into three specific phases: inflammatory phase, fibroblast proliferation, extracellular matrix deposition phase and remodeling phase $^{8}$. The characteristics of evolution on the site of injury is a result of a succession or combination of cellular and tissue events that are caused by chemical mediators and cellular activation ${ }^{8,9}$.

During a skin lesion, leakage of blood from damaged blood vessels and its constituents, such as vasoactive substances, adhesive proteins, growth factors and proteases, will occur ${ }^{10}$. Angiogenesis is a biological mechanism for new capillary formation. It involves the activation, migration, and proliferation of endothelial cells from pre-existing vessels ${ }^{11}$. Most likely growth factors are responsible for mitogens and hyperplasia of the epithelium ${ }^{10}$. The remodeling phase promotes a change in the composition of the extracellular matrix of fibers and cells, it is a period of consolidation and strengthening. The initial reinforcement is the deposition, clustering and collagen remodeling, and is responsible for the increased tensile strength and decreased scar size and erythema ${ }^{10,12}$. At this stage a progressive reduction of the neoformed vessels occurs, including cell elements and fibroblasts reduction, and the monostratified epithelium becomes stratified ${ }^{12}$.

Phytotherapic elixir sanativo $^{\circledR}$ is traditionally used in northeastern Brazil, it's composition consists of a hydroalcoholic extract from different plant species, among which angico (Anadenanthera colubrina Vell. Brenan) is included and indicated for its anti-inflammatory activities in the treatment of wounds. The presence of angico seems to be related to its hemostatic and healing activities ${ }^{4}$. Lima et al. ${ }^{4}$ studied the healing activity and preclinical toxicology of elixir sanativo ${ }^{\circledR}$ and observed its significant healing properties in the epithelial tissues.

Several studies have demonstrated healing effects of plants. Parente et al. ${ }^{13}$ studied the effect of ethanol extract of Calendula officinalis L. flowers in skin wounds of rats and observed healing activity with induction of neovascularization. The copaiba oil, a substance extracted from a plant found at the Amazon rainforest, was evaluated morphometric and morphologically in cutaneous wound healing in rats, demonstrating a capability to increase the granulation tissue and blood vessels ${ }^{13-15}$.

Based on positive data describing the angicos antibacterial properties and its use in folk medicine to promote healing and tissue repair, this study was carried out to evaluate the morphology and neoangiogenesis of cutaneous wounds in rats treated with angico (Anadenanthera colubrina var. cebil) hydroalcoholic extract at 5\%.

\section{Methods}

The study protocol was approved by the Animal Ethics Committee of the Federal Rural University of Pernambuco (UFRPE) (process n ${ }^{\circ}$ 23082.014123/2011).

Twenty adult male rats (Rattus norvegicus albinus) weighing approximately $300 \mathrm{~g}$ were obtained from the Morphology and Physiology Department of the Federal Rural University of Pernambuco (UFRPE). The animals were housed in individual boxes with commercial chow (Presence ${ }^{\circledR}$, Purina) and water ad libitum, maintained at $23-25^{\circ} \mathrm{C}$, under a 12 hour light/dark cycle, at the Pharmacy Department of the Federal University of Pernambuco (UFPE) animal colony.

After a week of adaptation to new environment animals were anesthetized with a combination of xylazine $(20 \mathrm{mg} / \mathrm{Kg})$ and ketamine $(100 \mathrm{mg} / \mathrm{Kg})$ intramuscularly administered ${ }^{15}$. The dorsal fur of the animals was shaved in the thoracic region and antisepsis was performed with topical alcoholic chlorhexidine $0.5 \%$. The area was initially marked with the aid of $1.3 \mathrm{~cm}$ diameter cylinder. With a surgical blade and blunt scissors, incisions were made in skin and subcutaneous tissue on the right and left sides of the thoracic region, separated by a $2 \mathrm{~cm}$ distance. The tissue was dissected and removed leaving adjacent fascia exposed.

Immediately after surgical excision the control (Ctrl) wounds located on the right antimere received daily topical applications of saline (sodium chloride $0.9 \%$ ), the treated (Treat) group with wounds located in the left antimere, received daily 
topical applications of alcoholic extract of "angico" $5 \%$.

The animals were then divided into four groups according to the time of application of the extract and normal saline. Group G4 - four days application, group G7 - seven days of application; group G14 - 14 days of application; group G21 - 21 days of application. Euthanasia was performed by increasing anesthesia.

Preparation of the extract of Anadenanthera colubrina var. cebil

The inner bark and outer bark of Angico (Anadenanthera colubrina var. cebil) were collected during the morning of the month of November in the city of Pombos, Pernambuco. The plant was identified by plant taxonomist by comparison with an exemplary deposited in the Sergio Tavares Herbarium of the Forest Science Department of UFRPE (specimen number: 17242).

The extract was prepared from the bark from a tree at the Pharmacy Department of the Pharmacognosy Laboratory, UFPE. After collecting, the material was air dried, milled, the powder obtained was weighed and diluted in $500 \mathrm{ml}$ methanol ${ }^{16}$. To obtain dry extract of $A$. colubrina var. cebil, after 12 hours the mixture was removed from the Soxhlet, filtered and concentrated in a rotary vacuum evaporator at $40^{\circ} \mathrm{C}$ to $45^{\circ} \mathrm{C}^{17}$. An aliquot equivalent to $5 \mathrm{~g}$ of this extract was diluted in $70 \%$ ethanol to yield the hydroalcoholic extract at 5\% and was kept in an amber glass container at room temperature until the experiment.

In addition, aliquots of the angico extract $(15 \mathrm{uL})$ (Anadenanthera colubrina var. cebil) were analyzed by thin layer chromatography (Merck silica gel. Article 105 553). Mobile phase chromatograms with different polarities were developed and their components were revealed according with the class of metabolites investigated $^{18,19}$. The presence of polyphenols (coumarins, anthraquinones, cinnamic derivatives, fenilpropanoglicosídeos, flavonoids, proanthocyanidins and gallic tannins), alkaloids and terpenoids (iridoids, mono and sesquiterpenes, triterpenes, steroids and saponósidos) was investigated.

\section{Morphology and morphometry}

Inhalation anesthesia with isoflurane was administered to animals from each group (G4, G7, G14 and G21), the wound was dissected with a $0.5 \mathrm{~cm}$ margin of healthy skin around the lesion. The fragments were quickly immersed in $10 \%$ formaldehyde for 24 hours and dehydrated in increasing concentrations of ethylic alcohol and diaphanized in xylene. Samples were then processed for paraffin inclusion. Longitudinal samples were obtained parallel to the greater axis of fragments and stained with hematoxylineosin (HE).
From paraffin-embedded blocks, 4- to $6-\mu \mathrm{m}$ sections were obtained. For each animal two cuts were made in the middle region of the flap. Sections were dried all night at $37^{\circ} \mathrm{C}$ and 30 minutes in $60^{\circ} \mathrm{C}$. Slides were immersed and dehydrated with xylene and alcohol. Afterwards, they were left in $3 \% \mathrm{H}_{2} \mathrm{O}_{2}$ for five minutes to prevent endogenous peroxidase activity. Slides were transferred to citrate-buffered solution ( $\mathrm{pH} \mathrm{6)}$ and processed in a microwave $(750 \mathrm{w})$ for five minutes twice. Then, slides were submitted to immunohistochemical staining with classic avidinbiotine peroxidase method for VEGF (VEGF -LabVision; 1/100). Immunohistochemical staining was performed with streptavidinbiotine-peroxidase method (UltraVision Polyvalent [rabbitmouse], LabVision Products) with horseradish peroxidase (HRP) kit. Diaminobenzidin was used as the chromogen.

Five images of each slide was obtained, always immediately below the crust, with the aid of a trinocular biological microscope (NIKON 50i) under 400X magnification and adjusted to a system that captures images. Quantification of newly formed vessels was performed in the center of the lesion in an area of 0.66 $\mathrm{mm}^{2}$ (imaging), with the aid of an image analyzer (Imagelab 2000) in a Windows operational system.

\section{Statistical analysis}

The data was evaluated by ANOVA complemented by Tukey-Kramer test $(p<0.05)$. Statistical analysis was performed using Assistat software, version 7.6 beta2.0.

\section{Results}

\section{Morphological}

No morphological differences were observed in group G4 lesions treated with saline or treated with angico hydroalcoholic extract. At this stage granulation tissue with many inflammatory cells, fibroblasts and blood vessels at the site of the lesion was observed. In the superficial portion of these lesions we observed the presence of a fibrin-leucocyte crust with high concentration of leukocytes in particular polymorphonuclear cells. However, in days 7 and 14 we noticed a more organized granulation tissue, a higher concentration of large fibroblasts, numerous collagen fibers and blood vessels that were oriented perpendicular to the surface of the wounds treated with angico extract when compared to those treated with saline (Figure 1). At the surface portion of the lesion we noticed the proliferation of the epithelial border below fibrinleukocyte crust, and was thinner in those treated with the angico extracts both at the 7 and 14 days, moreover on day 14 the lesion was covered by stratified epithelium. At day 21 both lesions had 
the same histological structure, consisting of dermis tissue and epidermal renewed tissue.

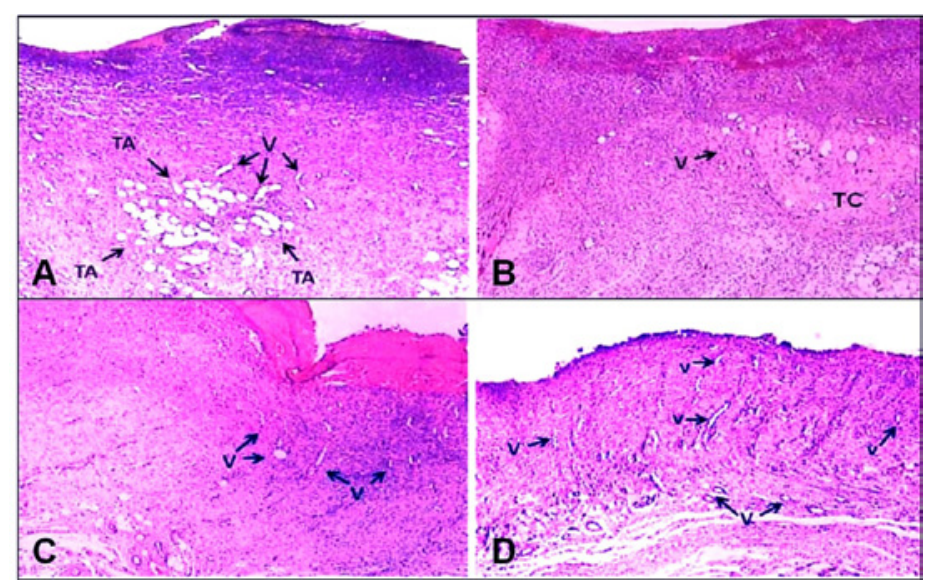

FIGURE 1 - Photomicrographs of skin fragments the rats at seven (A and $\mathbf{B}$ ) and 14 (C and D) days after surgery. In the treated side control observed presence of adipose cells (A) and the treated side (B) the presence of conjunctive tissue. In the 14 days after the lesion observed in $\mathbf{C}$ side control fibrin crust (CF) and in $\mathbf{D}$ treated side perpendicular numerous blood vessels. $\mathrm{V}=$ blood vessels, TA (adipose cells), $\mathrm{TC}=$ conjunctive tissue. H.E. 40x

\section{Morphometric}

Morphometric analysis of blood vessels stained by VEGF demonstrated an increase in the number of blood vessels in both wounds (treated with serum or with angico extract) at days 7 and 14 compared to days 4 and $21(p<0.01)$. These two periods (7 and 14) had a higher average number of blood vessels in the extract treated wounds when compared to those treated with saline $(p<0.001)$. We found no difference in the number of blood vessels in both the 4 th and the 21 st days of the wounds treated with serum or the extract (Figure 2).

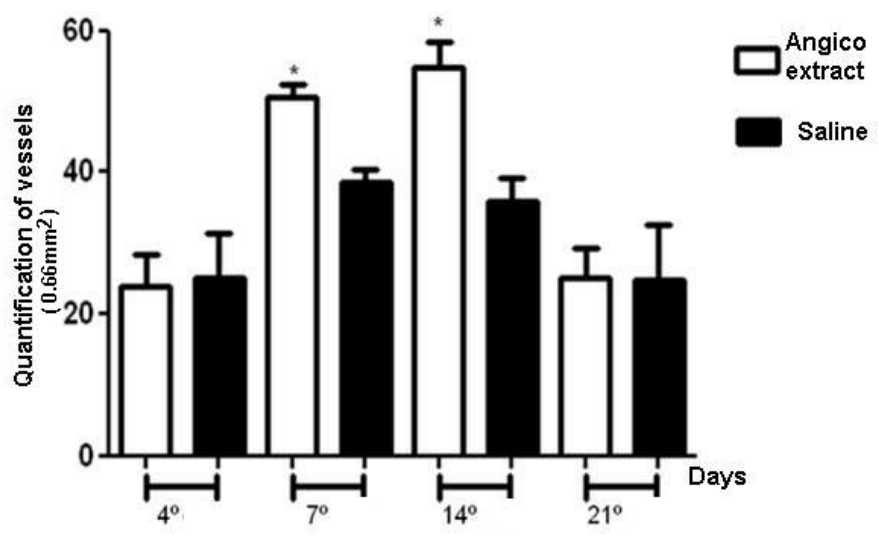

FIGURE 2 - Means and standard deviation of means of blood vessels numbers present in the control (saline) or treated lesions (angico extract) at days four, seven, 14 and 21 postoperatively $\left({ }^{*} p<0.01\right)$.

\section{Chromatographic analysis}

The chromatographic analysis was performed to determine the presence of metabolites in the angico hydroalcoholic, we identified the following constituents: flavonoids (quercetinic glycosides), saponins (saponosídos), triterpenes and weakly positive steroids, whereas reducing sugars, leucoanthocyanidins were moderately positive and condensed proanthocyanidins were strongly positive. Alkaloids gallic acid and ellagic acid were not identified (Chart 1).

CHART 1 - Metabolites found in the inner and outer bark of Angico (Anadenanthera colubrina var. cebil).

\begin{tabular}{|cc|}
\hline Metabolites & $\begin{array}{c}\text { Anadenanthera } \\
\text { colubrina }\end{array}$ \\
\hline Reducing sugars & ++ \\
Alkaloids & - \\
Flavonoids & + \\
(quercetinic glycosides) & - \\
Gallic acid & - \\
Ellagic acid & +++ \\
Condensed proanthocyanidin & ++ \\
Leucoantocyanidins & + \\
Saponins (saponosides) & + \\
Triterpens and steroides & + \\
\hline
\end{tabular}

Legend: $+=$ weakly positive; $++=$ moderatly positive; $+++=$ strongly positive; - = negative

\section{Discussion}

Our results demonstrated that, in both wounds of animals from G4 (day 4 post-lesion), granulation tissue, characteristically seen in the fibroplasia phase and wound healing, where the leukocytes migration and cell differentiation occur, in particular fibroblasts which is always accompanied by elevated cellular proliferation $^{21}$, could be observed. At the same day we noticed at the surface of both lesions a coating fibrin-leukocyte crust, rich in polymorphonuclear cells, which is in accordance with Castelo Branco Neto et al. $^{22}$ that studied lesions treated with aroeira hydroalcoholic extract. It should be noted that leukocytes, especially polymorphonuclear cells are the first defense cells of the organism to reach the site of tissue injury and remain there for a period of three to five days, their main function is to eliminate microorganisms which have possibly penetrated the lesion ${ }^{10}$.

At day four and seven post-injury fibroplasia and cell 
differentiation are extremely important in the development of granulation tissue. According to Balbino et al. ${ }^{8}$ extracellular matrix is produced with an increase of active fibroblasts (collagen fibers and amorphous substance), initially in a disordered pattern. However, after a certain period of time, the cells begin the tissue remodeling process; the extracellular matrix is replaced by an orderly connective tissue; in our experiment at day 21, the site of injury could not be identified since tissue was completely remodeled.

In the present experiment, dermis fibroblasts in wounds from day seven and 14 after surgery and treated with alcoholic extract of angico were larger when compared to those present in lesions treated with saline.

Vascular endothelial growth factor (VEGF) is an angiogenic peptide produced by endothelial cells, macrophages, and many other cells, being an excellent marker for endothelial cells ${ }^{23}$. Regarding blood vessels, we noted on day 4 that lesions treated with alcoholic extract of angico had various, mostly dilated lumens, and a thick crust of fibrin-leukocyte was present, at days seven and 14 there was more blood vessels, more dilated, especially in lesions treated with angico extract. In the lesions treated with saline, blood vessels were in a lower concentration both at days seven and 14, compared to those treated with saline.

In the initial stage of wound healing, drastic changes occur in microcirculation, increase in neovascularization and vascular permeability should occur, leading to edema and migration of leukocytes, particularly neutrophils and monocytes ${ }^{21,24}$. According to Khanna et al. ${ }^{6}$, angiogenesis plays a central role in wound healing. Among many known growth factors (epidermal growth factor-EGF; tumor necrosis factor-TNF-alpha; platelet-derived growth factors-PDGF; fibroblast growth factor-FGF, vascular endothelial growth factor-VEGF and the transforming growth factor beta-TGF-beta), the vascular endothelial growth factor plays an important role in the stimulation of angiogenesis in wounds $^{6,25}$ induces migration and proliferation of endothelial cells and increases vascular permeability ${ }^{26}$, in accordance with its supposed ability to promote angiogenesis ${ }^{6}$.

Studies conducted with copaiba oil in different experimental models of wound healing in rats, have demonstrated its capability to increase neoangiogenesis in the second phase of the healing process. Brito et al. ${ }^{14}$ and Estevão et al. ${ }^{15}$ reported evidence of increased number of more dilated blood vessels on wounds at day 7 post-operative, in accordance with results from our research. Parente et $a l .{ }^{13}$ in a study on angiogenesis activity of ethanol extract and dichloromethane and hexane fractions of the flowers of Calendula officinalis L. in skin wounds in rats have demonstrated a positive effect on promoting wound healing angiogenesis, which corroborates with our findings.

The angico is a native tropical America tree and present in the Brazilian cerrado, exploited and / or cultivated mainly due to wood quality, its inner and outer bark is used popularly as a medicinal plant as a healing agent and for various other purposes. Lima et $a l .{ }^{4}$ in a study using the sanative Elixir ${ }^{\circledR}$ prepared from the combination of hydroalcoholic extracts of different plant species, including the Angico extract, demonstrated its significant wound healing properties.

According Gomes de $\mathrm{Melo}^{27}$ the Angico extracts are chemically constituted by indole alkaloids (oxide of $\mathrm{N}$, N-dimethyltryptamine), sterols (sitosterol palmitate and $\delta$ - $\delta$-sitosterol), flavonoids $\left(3,3^{\prime}, 4^{\prime}, 7,8\right.$ - pentahidroflavona), terpenoids (lupenona and lupeol) phenol derivatives (3,4,5-dimethoxidalbergiona, and dalbergiona kuhlmannia) and tannin in the inner bark ${ }^{2}$ also known as proanthocyanidins. Proanthocyanidins and other tannins are known to facilitate wound healing ${ }^{5,6}$. Khanna et $a l .{ }^{6}$ studied the topical application of grape seed extract, which has appreciable amounts of proanthocyanidins in the process of wound healing in rat skin, and reported it has a specific effect on the induction and regulation in angiogenic genes transcription, also suggesting vascular endothelial growth factor (VEGF) activity. We identified large quantities of proanthocyanidins in our study with the Angico hydroalcoholic extract 5\% (ethanol 7:3 $\mathrm{H}_{2} \mathrm{O}$ ) from the inner and outer bark (Anadenanthera colubrina var. cebil).

Lesions on day 21, had no significant differences between those treated with saline and treated with the angico alcoholic extract, blood vessels were in lower concentrations compared with seven and 14 days, with reduced lumens, completely reconstituted epithelium, and moderate concentration of fibroblasts and collagen fibers. This data is supported in most studies, indicating that at this stage the injury process is already well resolved.

Morphology and morphometric analysis demonstrated improvement in the healing process of lesions treated with Angico alcoholic extract, on the days seven and 14 after surgery. However, at day 21 both lesions were very similar in tissue remodeling.

\section{Conclusion}

The angico alcoholic extract (Anadenanthera colubrina var. cebil) induces the acceleration of wound healing in skin wounds of rats. 


\section{References}

1. Schultes RE. Amazonian ethnobotany and the search for new drugs. Ciba Found Symp. 1994;185:106-12.

2. Paes JB, Diniz CEF, Marinho IV, Lima CR. Avaliação do potencial tanífero de seis espécies florestais de ocorrência no semiárido brasileiro. Cerne, Lavras 2006;12(3):232-8.

3. de Albuquerque UP, Soldati GT, Sieber SS, Ramos MA, de Sá JC, de Souza LC. The use of plants in the medical system of the Fulni-ô people (NE Brazil): a perspective on age and gender. J Ethnopharmacol. 2011;133(2):866-73.

4. Lima CR, Costa-Silva JH, Lyra MMA, Araújo AV, Arruda VM, Dimech GS, Baratella-Evêncio L, Fraga MCCA, Lafayette, SSL, Wanderley AG. Atividade cicatrizante e estudo toxicológico préclínico do fitoterápico Sanativo ${ }^{\circledR}$. Acta Farmacol Bonaerense. 2006;25(4):544-9.

5. Leandro LM, Vargas Fde S, Barbosa PC, Neves JK, da Silva JA, da Veiga-Junior VF. Chemistry and biological activities of terpenoids from copaiba (Copaifera spp.) oleoresins. Molecules. 2012;17(4):3866-89.

6. Khanna S, Venojarvi M, Roy S, Sharma N, Trikha P, Bagchi D, Bagchi M, Sen CK. Dermal wound healing properties of redoxactive grape seed proanthocyanidins. Free Radic Biol Med. 2002;33(8):1089-96.

7. Palmeira JD, Ferreira SB, Souza JH, Almeida JM, Figueiredo MC, Pequeno AS, Arruda TA, Antunes RMP, Catão RMR. Avaliação da atividade antimicrobiana in vitro e determinação da concentração inibitória minima (CIM) de extratos hidroalcoolicos de angico sobre cepas de Staphylococcus aureus. RBAC. 2010;42(1):33-7.

8. Balbino CA, Pereira LM, Curi R. Mecanismos envolvidos na cicatrização: uma revisão. Rev Bras Ciênc Farmacol. 2005;41(1):2751.

9. $\mathrm{Ng}$ MF. The role of mast cells in wound healing. Int Wound J. 2010;7(1):55-61.

10. Mandelbaum SH, Di Santis EP, Mandelbaum MHS. Cicatrização: conceitos atuais e recursos auxiliares. Parte I. An Bras Dermatol. 2003;78(4):1-16.

11. Liapakis I, Anagnostoulis S, Karayiannakis A, Korkolis D, Lambropoulou M, Matarasso A, Simopoulos M. Burn wound angiogenesis is increased by exogenously administered recombinant leptin in rats. Acta Cir Bras. 2008;23(2):118-24.

12. Corsi RCC, Corsi PR, Pirana S, Muraco FAE, Jorge D. Wound healing. A review. Rev Col Bras Cir. 1994;84(1):17-24.

13. Parente LML, Andrade MA, Brito LAB, Moura VMBD, Miguel MP, Lino-Júnior RS, Tresvenzo LFM, Paula JR, Paulo NM. Angiogenic activity of Calendula officinalis flowers L. in rats. Acta Cir Bras. 2011;26(1):19-24

14. Brito NMB, Simöes MJ, Gomes PO, Pessoa AF, Melo MCF. Aspectos microscópicos da cicatrizaçäo de feridas cutâneas abertas tratadas com óleo de copaíba em ratos. Rev Paraense Med. 1999;13(1):12-7.

15. Estevão LRM, Medeiros JP, Scognomillo-Zsabó MVR, BaratellaEvêncio L, Guimarães EC, Câmara CAG, Evêncio-Neto J. Neoangiogênese de retalhos cutâneos em ratos tratados com óleo de copaíba. Pesq Agr Bras. 2009;44(4):406-12.

16. Pansera MR, Iob GA, Atti-Santos AC, Rossato M, Atti-Serafini L, Cassel E. Extraction of Tannin by Acacia mearnsii with supercritical fluids. Braz Arch Biol Tech. 2004;47(6):995-8.

17. Ferrari RA, Colussi F, Ayub RA. Characterization of by-products of passion fruit industrialization utilization of seeds. Rev Bras Frutic. 2004;26(1):101-2.

18. Lopes ES. Revisões de conjunto. Aplicações da cromatografia em camada fina à análise farmacêutica. Rev Port Farm. 1965;15:10527.
19. Markham KR. Techiniques of flavonoid identification. London: Academic Press; 1982.

20. Souza MD, Peres Filho O, Dorval A. Efeito de extratos naturais de folhas vegetais em Leucoagaricus gongylophorus (Möller) Singer, (Agaricales: Agaricaceae). Ambiência. 2011;7(3):461-71.

21. Mondolin M, Bevilacqua RG. Cicatrização das feridas. Síntese das aquisições recentes. Rev Bras Clin Terap. 1985;14(6):208-13.

22. Castelo Branco Neto MLC, Ribas Filho JM, Malafaia O, Oliveira Filho MA, Czeczko NG, Aoki S, Cunha R, Fonseca VR, Teixeira HM, Aguiar LRF. Avaliação do extrato hidroalcoólico de aroeira (Schinus terebinthifolius Raddi) no processo de cicatrização de feridas de pele em ratos. Acta Cir Bras. 2006;21(Supl 2):17-22.

23. Soyer T, Ayva S, Aliefendioğlu D, Aktuna Z, Aslan MK, Senyücel MF, Cakmak M. Effect of phototherapy on growth factor levels in neonatal rat skin. J Pediatr Surg. 2011;46(11):2128-31.

24. Simões MJ, Cabral ACV, Boyaciyan K, Kulay Jr L, Sasso WS. Aspectos ultra-estruturais dos fibroblastos e dos macrófagos durante o processo de reparação da pele de ratos. Rev Paul Med. 1986;104(3):132-5.

25. Nissen NN, Polverini PJ, Koch AE, Volin MV, Gamelli RL, DiPietro LA. Vascular endothelial growth factor mediates angiogenic activity during the proliferative phase of wound healing. Am J Pathol. 1998; 152:1445-52.

26. Inoue $\mathrm{M}$, Itoh $\mathrm{H}$, Ueda $\mathrm{M}$, Naruko $\mathrm{T}$, Kojima $\mathrm{A}$, Komatsu R, Doi K, Ogawa Y, Tamura N, Igaki T, Yamashita J, Chun TH, Masatsugu $\mathrm{K}$, Becker AE, Nakao K. Vascular endothelial growth factor (VEGF) expression in human coronary atherosclerotic lesions: possible pathophysiological significance of VEGF in progression of atherosclerosis. Circulation. 1998;98:2108-16.

27. Gomes de Melo J, de Sousa Araújo TA, Thijan Nobre de Almeida e Castro V, Lyra de Vasconcelos Cabral D, do Desterro Rodrigues M, Carneiro do Nascimento S, Cavalcanti de Amorim EL, de Albuquerque UP. Antiproliferative activity, antioxidant capacity and tannin content in plants of semi-arid northeastern Brazil. Molecules. 2010;15(12):8534-42.

\section{Acknowledgments}

To José de Castro Souza Neto Junior and Haroudo Satiro Xavier from the Department of Pharmacology, Federal Rural University of Pernambuco (UFRPE), Brazil, for technical support.

\section{Correspondence:}

Joaquim Evêncio-Neto

Universidade Federal Rural de Pernambuco/DMFA

Rua Manoel de Medeiros, $\mathrm{s} / \mathrm{n}^{\circ}$ Dois Irmãos

52171-900 Recife - PE Brasil

evencio@dmfa.ufrpe.br

Received: May 14, 2012

Review: July 16, 2012

Accepted: August 15, 2012

Conflict of interest: none

Financial source: none

${ }^{1}$ Research performed at Animal Department of Pharmacy, Federal University of Pernambuco (UFPE). Part of PhD degree thesis, Postgraduate Program in Animal Bioscience. Tutor: Joaquim Evêncio-Neto. 